\title{
Expropriations of foreign property and political alliances: a business historical approach
}

\author{
Marcelo Bucheli \\ University of Illinois at Urbana-Champaign \\ Wohlers Hall 190, \\ 1206 South Sixth Street, \\ Champaign IL 61820, USA. \\ E-mail: MBucheli@illinois.edu
}

\author{
Stephanie Decker \\ Aston Business School \\ Aston University \\ Aston Triangle \\ Birmingham B4 7ET \\ S.Decker@aston.ac.uk
}

\section{Note:}

The authors are listed alphabetically; both contributed equally to the article. We are grateful for the feedback and comments on previous versions of this paper in presentations at the World Economic History Conference (Stellenbosch, 2011; Boston, 2018), Business History Conference (Philadelphia, 2012), World Business History Conference (Frankfurt, 2014), Academy of International Business (Copenhagen, 2019), Universidad de los Andes (Bogotá, 2012), Florida International University (Miami, 2010), École Polytechnique (Paris, 2014), and University College of London (2019). We give special thanks to Stephen Kobrin, Rory, Miller, Aldo Musacchio, Thilo Jungkind, Eric Godelier, Hervé Dumez, Noel Maurer, Carlos Dávila, Kenneth Lipartito, Jason Yackee, Lauge Poulson and Mira Wilkins. We also thank the Andrew Popp as the journal editor and anonymous referees for their suggestions.

\section{Biographies:}

Marcelo Bucheli is associate professor at the Gies College of Business, University of Illinois at Urbana-Champaign, USA. He conducts research on the political economy of foreign direct investment and the integration of historical research with management studies.

Stephanie Decker is professor of organization studies and history at Aston Business School, Birmingham, UK. Her research focuses on the history of business in subSaharan Africa and the use of historical approaches in management and organization studies. 


\section{Expropriations of foreign property and political alliances: a}

\section{business historical approach}

\section{Abstract}

This paper proposes a classification of government expropriations of foreign property based on the types of alliances sought out by governments in their quest for support for those actions. Based on a review of historical literature and social science studies of expropriations in Sub-Saharan Africa and Latin America in the twentieth century, we define three types of alliances: with organized labor; with domestic business owners or with sections of the civil service or the ruling party. We posit that each sector allying itself with the government expects rewards from the expropriation. We maintain that the type of alliance is determined by several factors, in particular, the longevity and legitimacy of the nation-state of the expropriating country; the strength of organized labor; and the political participation and strength of the domestic business sector. Our framework complements existing studies explaining when and why expropriations take place.

Keywords: expropriation - economic nationalism - nationalization - indigenization political alliances - comparative historiography 


\section{Introduction}

Over the twentieth and twenty-first centuries, the world has witnessed three periods during which several governments took over the assets belonging to foreign investors operating in their territory. The first wave of expropriations took place in the 1920s and 1930s when revolutionary governments expelled foreign firms (particularly in the energy sector) and replaced them with domestic state-owned firms. ${ }^{1}$ The second and largest wave occurred in the 1960s and 1970s when the governments in Latin America and recently decolonized African and Asian countries took over the operations of major multinational corporations in the natural resource, infrastructure, and industrial sectors. ${ }^{2}$ The third wave of expropriations took place in the early twenty-first century. Due to the historical approach of this paper, we do not analyze that wave but hope our taxonomy will provide analytical tools to understand it. ${ }^{3}$ These very visible instances of economic nationalism against foreign investors have been widely researched in business history, political economy, and international business. While political economy and international business have sought to establish general theories that explain expropriations across time and space, ${ }^{4}$ international business history has often focused on discrete instances of expropriations, explaining the historical particularities of individual cases. ${ }^{5}$

We argue that to conduct an expropriation of foreign private property, a government needs to build an alliance of different actors that expect to gain some rewards from the expropriation. We maintain that the nature of the alliance depends on several characteristics of the host country that include the longevity and legitimacy of the nationstate and the strength of organized labor. Our definition of the different types of political alliances contributes to existing explanations of when and why expropriations take place. 
Political alliances help us to understand how the expropriations take place in terms of the political strategies behind these actions. Based on our case narratives, we define three distinct types of alliances built to conduct expropriations of foreign property:

(a) A political alliance between the government and the domestic organized labor

(b) A political alliance between the government and domestic business owners

(c) A political alliance between the government and domestic civil servants.

We do not believe that this framework of different domestic political alliances which drive the timing and form of expropriations are exhaustive, but rather that they establish an important pattern that can only be seen by comparing the rich and detailed historical accounts of individual cases. We hope our paper can be a starting point for other studies defining other types of alliances with other constituencies.

We conduct our study through a comparative historiography approach. This means we draw on a synthesis of existing historical (and social-scientific) accounts in place of direct archival research. This approach was first advocated in 1958 by Fritz Redlich, in recognition of the valuable and reliable archival research that underpins historical research monographs. He questioned why historians would frown on the “systematic use of the resulting material, derisively called 'secondary,' [which] appears as somewhat absurd, when the goal is highly sophisticated synthesis and not a mere narrative. ${ }^{96}$ Business history in particular has relied on single case studies, with comparative or industry-wide research being less common. Similar concerns about the lack of structured approaches to synthesize the insights from individual studies, has led to 
the development of explicit approaches to synthesis in related research areas, such as meta-ethnography. ${ }^{7}$

To our knowledge, few scholars have sought to explain the differences between full and partial expropriation, as well as nationalization vs. indigenization. ${ }^{8}$ Scholars have noted that economic nationalism may occur on a sliding scale ranging from punitive taxation, over local content requirements to complete expropriations. ${ }^{9}$ Others have focused on the timing of expropriation, or which industries have been targeted. ${ }^{10}$ However, we believe that there are important domestic political, social, and economic factors that influence how countries seek to enact expropriations that are relevant to understand their historical trajectories. To elaborate our point, we compare the history of seven countries in Latin America and sub-Saharan Africa to show that expropriations followed different political agendas.

Due to the geographic and temporal range of our cases, we do not present primary archival research, which would be beyond the scope of an article. As historians, we believe in the value of primary archival research to obtain new knowledge of the past, but we also see a role for comparative historiography that allows us to build on the existing knowledge from multiple in-depth historical case studies across different regions.

\section{The Expropriation of Foreign Property: Why, Where, and When}

Existing explanations for the expropriation of foreign property mostly come from other social science disciplines, such as international business, international political economy, and international law. They mostly take a broader, more international view that aims to 
theorize the conditions under which states may take foreign property. These explanations converge around a set of reasons for expropriations listed in table 1. Authors do not necessarily put forward a single explanation at the expense of all others, as becomes clear from the list below, but combine different reasons in their argumentation of why, where and when expropriations occur.

\section{Table 1 about here}

When trying to understand why developing countries expropriate foreign property, explanations have focused on abstract concepts such as ideology, symbolism, and fairness. For example, rulers who perceive that the country's level of poverty is the result of a history of foreign exploitation might decide to ensure national control over "the commanding heights of the economy," that is to say, over strategically important industries. ${ }^{11}$ Kobrin, however, cautioned that ideology's role as the main driver for expropriation only applies for the mass expropriations resulting from state takeovers led by Communists. ${ }^{12}$ Another justification for expropriation may be based on the unwillingness of multinationals to re-negotiate existing contracts that are perceived as unfair to the host country. ${ }^{13}$

However, not all explanations perceive ideology or symbolism as key to decisionmaking and instead assert that governments expropriated because they had gained the capability through acquisition of technology or because the international conditions were favorable to expropriations. ${ }^{14}$ Most studies of expropriations, however, went beyond 
these general explanations of why this occurred towards taking into account the where and when as well. ${ }^{15}$

Apart from the mass expropriations in Eastern Europe after World War II, most expropriations of foreign property in the twentieth and twenty-first centuries have occurred in less developed or emerging economies. This has led many scholars to focus on where expropriations take place. Explanations broadly focus on 1) the industrial sector affected by the expropriation, and 2) the institutional characteristics of the expropriating nation-state. Expropriations in the natural resource sector (including oil, mining, and agriculture) represented around 40 percent of all expropriations during the 1960s-1970s wave. ${ }^{16}$ Although those expropriations garnered the most press coverage and prompted the most diplomatic tensions, that wave of expropriations also included a significant amount of expropriations in the manufacturing sector (27 percent) followed by finance (12 percent) and trade (5 percent). ${ }^{17}$ In the great majority of the cases (90 percent), the expropriations were selective, as they targeted particular firms or industries. ${ }^{18}$ The strategic importance of the sector for the expropriating country is key to understanding this pattern.

Many scholars have assumed that democracies are more effective at protecting foreign investors than autocratic states. ${ }^{19}$ However, others have argued that in countries where political turnover is high (whether they are democracies or dictatorships), rulers will assume a short-term horizon in defining their actions and will be tempted to expropriate foreign firms and obtain the short-term gains from the expropriation without dealing with the long-term problems. ${ }^{20}$ Ultimately, many scholars agree that expropriations are more likely to occur in countries with "weak institutions," usually 
defined (as critics have pointed out) as not sharing the institutional framework of Western liberal democracies. $^{21}$

Using a neo-Marxist lens, the so-called dependency scholars studied expropriations as one of the tools used by peripheral countries' dominant classes to reduce their subordinate role in the global economy. For Dos Santos, the expropriations of export industries that took place in Latin America in the 1930s and later on in the 1960s aimed to gain domestic control over the main source of hard foreign currency. ${ }^{22}$ The rationale, according to Dos Santos, of these initiatives was to use this foreign currency to fund an industrialization process that would eventually break the expropriating country's dependency status. By the very nature of how the world economic system works, Dos Santos posited, this end of the dependent status never materialized, but was replaced by another type of dependence. Evans confirms this point by showing how hard it was for the Brazilian bourgeoisie to control multinational corporations (particularly in research and development) while at the same time trying to increase the nation's economic output. ${ }^{23}$ Dos Santos added that in the 1960s and 1970s the peripheral bourgeoisie took advantage of what they perceived as a general weakening of the United States in the global sphere (reflected in the catastrophic Vietnam war) to either expropriate foreign property for their development programs or to take initiatives to collectively weaken the power of the multinationals with organizations such as OPEC or the Non-Aligned Countries. ${ }^{24}$ Regardless of any revolutionary language used by most expropriating governments, most dependency scholars agree with the idea that the working classes did not usually lead expropriations. ${ }^{25}$ 
Studies addressing when expropriation is likely to occur, focus on the technical characteristics of the expropriated firm or industry, the evolution of international prices of the product under foreign control, and general international trends in the political economy. Kobrin provides a simple explanation of the rationale of expropriation policies by arguing that, once the benefits of placing a particular industry in foreign hands no longer justify the costs and regulation involved, a government might find it more beneficial to expropriate. ${ }^{26}$ Combining several of the previous elements in a single model, Medina, Marcelo, and Kim maintain that expropriation of foreign firms is more likely to take place when the host government has limited capability to monitor taxation (after all, taxation of several industries can be highly complex and requires particular know-how the local government might not have), its economy has acquired capabilities to run the industry, the host country's economy does not depend significantly on exports controlled by foreign firms, and political competition is restricted. ${ }^{27}$ Movements of international commodity prices can also account for industry-specific expropriations, for example, the link between high oil prices and oil company expropriations. This dynamic is frequently most evident in more autocratic host countries, combining a range of different reasons to account for these events. ${ }^{28}$

In summary, existing explanations cover a wide range of reasons for expropriations, but even these do not fully explain all cases of expropriation. We maintain that closer attention to the specific national contexts and the convergence of domestic interest groups are important, yet undertheorized in terms of how expropriations occur. Our comparative historiography offers an alternative framework that is more responsive to the kind of contextual, contingent, and temporally unique features of 
expropriations in developing countries. We believe that historical research's strengths in attending to the specific and unique in the analysis of historical events offers an alternative mode to creating theoretically relevant explanations.

\section{Selecting cases of expropriation in Latin America and sub-Saharan Africa}

Our synthesis focuses on historical research on expropriations in developing countries in the mid-twentieth century, a period that saw a large number of expropriations. Expropriation is defined as a "governmental action to transfer the ownership of private (in this case, foreign) assets to the state, with or without compensation" 29 or "the forced divestment of equity ownership of a foreign direct investor." ${ }^{30}$ We consider cases in which the government forces the divestment of foreign-owned assets either to redistribute them among a particular domestic constituency (referred to as indigenization) or to be owned by the government (nationalization). In this study, we do not consider cases of "creeping expropriation" defined as cases "when governments change taxes, regulation,

access, and laws to reduce the profitability of foreign investment." ${ }^{31}$ We also distinguish between nationalization and indigenization as two different forms of expropriation that are usually lumped together. ${ }^{32}$

For this article, we chose to discuss several paradigmatic cases of expropriation. The one taking place in Mexico in 1938 was the largest one at that time outside the Communist world. Venezuela was a major oil producer in the 1970s and has previously led the creation of OPEC. The conflicts between the Chilean government and foreign firms eventually led to the establishment of one of the longest military dictatorships in the 
Americas. Ghana and Nigeria were the two most extensive cases of indigenization degrees. Zambia's copper nationalization was seen as a response to the Chilean decrees, and Tanzania's nationalizations in response to the Arusha declaration was one of the few cases in Africa that were influenced by political ideology.

While nationalization means that the government expropriates and takes over shares and assets, in the case of indigenization the government enacts legislation that requires foreign investors to sell part or all their shares or assets to a domestic owner. This was an important factor in our selection of cases, as we were interested in why governments would choose one form of expropriation over another. Indigenization-type expropriation was more common in sub-Saharan Africa, so we selected two well-known and significant cases (Ghana and Nigeria) to compare them to well-known and significant cases in Latin America (Mexico, Chile, and Venezuela). However, sub-Saharan Africa also had well-known cases of nationalization, so we added Zambia and Tanzania for further comparison. We were not aware of any significant cases of indigenization in Latin America. All of these cases saw significant expropriations, by which we mean the size and scale of expropriations of foreign property were considered sizeable at the time. ${ }^{33}$ They also suggest having categories that differ on key dimensions, which for our cases are geography and type of expropriation (see figure 1). Finally, we also considered whether there had been historical research on these cases for us to synthesize.

Insert Figure 1 about here 
We searched for literature on our cases based on prior knowledge, general historical accounts, hand-searching, and following up references. Historical research on our theme was rarely in the form of a standalone study or monograph solely dedicated to the subject, but rather formed part of other research controversies or a holistic account of a historical period. As a result, the terminology used by authors varied, making it difficult to conduct focused systematic searches through standard software tools. Ultimately, we selected studies that were either historical narratives based on archival sources ${ }^{34}$ or by now historical accounts by social scientists at the time. ${ }^{35}$ While most historiographical accounts follow established research controversies, our comparative historical analysis of our cases showed relatively little overarching debate or cross-citation. We compiled preliminary case histories for our seven cases, focusing on domestic political processes and actors in their explanations. We then compared within and across cases to develop analytically structured histories for comparison. ${ }^{36}$

\section{Expropriations of Foreign Property in Latin America and Sub-Saharan}

\section{Africa}

Expropriations in the twentieth century took place in two waves and mostly occurred in developing countries. ${ }^{37}$ During the 1920s and 1930s, the most important events of the first wave took place in Latin America and Eastern Europe. ${ }^{38}$ During World War II, the United States and their allies expropriated German property in their territories and, shortly after the end of the war, Soviet-occupied territories also expropriated both domestic and foreign property as part of their agenda of eliminating private property. 
During the early 1960s (the first years of the second wave), most expropriations took place in Asia, but from 1967 onward, the great majority of expropriations took place in Africa and Latin America (see Figure 2). ${ }^{39}$

\section{Figure 2 about here}

From our comparison between our seven cases, it became clear that different domestic groups supported nationalization or indigenization legislation. For the Latin American cases, the role of the labor movement stood out, but this was not the case in the subSaharan African countries. These also showed a marked difference in terms of the type of expropriation: indigenization decrees in West Africa were broadly supported by a more or less organized domestic business community, whereas nationalizations in East Africa appeared to be driven by different groups within the government or the ruling party. We structure our historical narrative to reflect these insights.

\section{Government Alliances with Organized Labor}

The labor movement has played a significant and active role in governments' decision to expropriate foreign-owned property in several countries. If the government's alliance included the labor force working for the foreign firms and the workforce was sufficiently organized, the government responded to conflicts between labor and multinationals by supporting domestic workers, and not the foreign investor. These political alliances can shift over time, and policies towards foreign firms change accordingly. We find clear 
examples illustrating these changes in the case of the Mexican and Venezuelan oil industries and the Chilean copper industry.

The Mexican oil history constitutes a classic example of an expropriation resulting from changes in the government's political alliance. General Porfirio Díaz ruled Mexico from 1876 to 1910 . Díaz brought stability to the country after decades of political chaos, internal and external wars by ruling with an iron fist while simultaneously opening the doors to foreign investors. Díaz's rule perfectly exemplified a regime supported by a small political alliance. He restricted political freedoms and created a system in which most economic rents were distributed among those belonging to his inner political circle: "Díaz realized that to co-opt potential opponents he needed to reward them with rents. He also realized that to generate those rents; he needed to promote investment. Promoting investment required that Díaz specify and enforce property rights as private, not public goods." ${ }^{40}$ Díaz achieved this through two means: by passing legislation that was very favorable to foreign oil companies and by creating a larger system in which the regional elites benefited from the operations of foreign corporations. The British oil firm Pearson and Son exemplifies how the system worked, as its board featured the most influential individuals in Mexico, including Díaz’s son. ${ }^{41}$ During his rule, Díaz oversaw legislation that favored the operations of foreign corporations, including those operating in the oil sector. In short, the Díaz alliance included the foreign investors and segments of the national elite and excluded other groups of the Mexican society.

Events after 1910 suggest that the government's winning alliance was changing concerning the political system created by Díaz. Frustrated at what they considered to be a policy that only benefited a small circle of Díaz's friends, members of the Mexican elite 
overthrew Díaz. This action led to the widespread uprising known as the Mexican Revolution. In 1915, amid a civil war, a revolutionary faction led by Venustiano Carranza took power in Mexico City and launched a process to change the country's institutional framework. His government was responsible for the 1917 Constitution that granted the government legal rights over the country's subsoil and for increased taxation of the oil multinationals, precisely when oil prices were rising sharply. ${ }^{42}$ Even though this stopped short of expropriation, the multinationals considered these actions as confiscatory and the US and British governments condemned the new legislation. These reactions clearly show that the alliance with foreign investors had been broken and Carranza sought a new alliance with the domestic business elite. The Constitution, however, remained unchanged. In 1920 Carranza was overthrown by one of his generals, Alvaro Obregón, who immediately faced strong resistance from some of the other members of the military who remained loyal to Carranza. Obregón responded by creating an alliance with peasants and labor unions. Under Obregón's rule, a powerful labor federation was created (the CROM), which became crucial to ensuring his political survival. ${ }^{43}$ Despite his approach to the labor unions, Obregón promised the United States that he would refrain from taking measures against US oil companies in exchange for the neighboring country's official recognition as Mexico's legitimate president (a necessary gesture, as the civil war had not yet concluded). Tensions with the United States rose once again under Obregón's successor between 1924 and 1934, as the government increasingly demanded greater concessions from the multinationals, again stopping short of expropriation. During this period, the productivity of the Mexican oil industry began to decrease, and the oil firms gradually started moving to the more productive oilfields of 
Venezuela, which was politically more accommodating to foreign investors. ${ }^{44}$ Mexico's rulers increased the size of their political alliance by approaching the national industrial elite while remaining allied to the coopted labor unions. So, the government was building an alliance with domestic business owners, but not to have it as a support for expropriation.

In 1934, Mexico elected Lázaro Cárdenas as president. It is in this phase that the shifting political alliances became favorable to expropriation. Cárdenas took power at a moment in which the country had finally achieved political stability and wanted to consolidate his party's power by strengthening its ties with the labor movement. In 1938, oil workers went on strike demanding higher wages. The multinationals refused, and the unions took the case to the Mexican Supreme Court, which ruled in favor of the unions. When the multinationals refused to comply, Cárdenas decreed the complete nationalization of foreign oil property in Mexico. Taking control of the expropriated assets, the government created a state monopoly (PEMEX), which became an important base of support for Cárdenas' government.

Changes in the size and composition of the Venezuelan government's winning alliance also played a role in the nationalization of its oil industry in 1976. Contrary to the Mexican case, however, this initiative did not come from a left-wing party and did not face opposition from the US government. Oil multinationals arrived in Venezuela in the 1920s during the dictatorship of Juan Vicente Gómez (1908-1935). Gómez repressed labor unionism and opposition parties while creating a favorable business environment for foreign oil firms. This meant that Gómez built a clear alliance with foreign direct investors. In 1918 he even invited the multinationals to write the oil legislation 
themselves. Gómez created a concession system under which many domestic landowners applied for concessions and then sold them to foreign firms, making handsome profits in the process. These individuals and families, together with the multinationals and members of the army, became Gómez's political alliance and, during his rule, he accordingly managed the country's economic policy to their benefit. Gómez died in 1935 while still in power.

Following Gómez's death, Venezuela was ruled by military dictatorships until 1959 (with a brief pause when the center-left Acción Democrática Party, or AD, ruled between 1947 and 1948). During these years, the policy towards foreign oil firms consisted mostly of increasing taxes. The banned pro-democracy opposition argued that the resulting higher government income was used mostly to reward those close to the dictators. Venezuela returned to civilian rule in 1959 under an AD that shifted its original left-wing position to the center by increasing the budget for the military, promising to respect the property rights of the landowning elites, decreasing taxation, and slowing social reforms. Starting that year, Venezuela approved a series of laws that increased government participation in oil profits (forced partial nationalization) and limited the arrival of new foreign firms. ${ }^{45}$ Social programs were funded by the taxes paid by foreign firms rather than the domestic private sector. ${ }^{46}$ This shows that the previous alliance between the government and foreign investors was gradually breaking.

The main opposition party was the center-right COPEI (the Comité de Organización Política Electoral Independiente, also known as the Social Christian Party). After winning the presidential election in 1969 despite its right-wing leanings, the COPEI leadership also demonstrated openness to the idea of nationalizing the oil industry. By 
this time, Venezuela had a sizable middle class with the necessary technical skills to run the industry, a sophisticated industrial elite, and a stable democratic regime, meeting several of the preconditions for a government to be capable of expropriating and running a company or sector, as pointed out by Kobrin. ${ }^{47}$ In 1970 , the center-right COPEI nationalized the gas industry and announced complete government ownership of oil fields by 1983 . This action showed that COPEI could not build a powerful enough political alliance for the 1974 elections without a nationalist platform. AD, however, still took power in 1974, but by that time, both parties agreed on the idea of domestic ownership of the oil industry, especially at a time when oil prices were rising sharply. ${ }^{48}$ This step was taken in January 1976, when an AD Venezuelan government took control of the domestic oil industry and created the state-owned enterprise Petróleos de Venezuela (PDVSA), turning foreign multinationals already present into contractors. Between 1977 and 1999, PDVSA played an important part in generating employment for the AD's base while the AD also controlled the firm's union, which had the power to mobilize voters in their favor. $^{49}$

Other expropriations were initiated by center or center-right regimes that had the support of a relatively large alliance composed of middle and working-class supporters. In 1964, Christian Democrat Eduardo Frei was elected as president of Chile and his constituency was composed of the middle class and some sectors of the working class distrustful of the left. Frei's political platform included increases in welfare spending, protectionism, and the nationalization of the foreign-dominated copper and telecommunications industries, which were both in the hands of American multinationals: Anaconda, Kennecott and Cerro Corporation for the copper industry and the International 
Telephone and Telegraph (ITT) for telecommunications. Frei opted for a policy he called the "Chileanization" (partial nationalization) of the copper industry which aimed to increase domestic ownership to 51 percent after negotiations with the multinational Anaconda. This policy was developed in a context in which rising copper prices throughout the 1960s boosted revenues in that sector.

Additionally, as was the case for Venezuela in the 1960s, by this time, Chile had developed its domestic capabilities to exploit this sector. ${ }^{50}$ Frei also created a stateowned telecommunications firm to compete with ITT. These initiatives were widely supported by the middle and working-class public and faced little opposition in Parliament. ${ }^{51}$ In 1970, Marxist Salvador Allende won the presidential election supported by a broad alliance composed of left-wing peasant and industrial labor unions, an important segment of the urban shantytowns' population, also attracting some middleclass supporters. Despite Allende's ideological differences with his centrist predecessor Frei, economic nationalist policies continued to have strong popular support. Allende's anti-imperialistic and Marxist discourse made expropriation consistent with his ideology. In 1971, Allende declared the expropriation of the properties of Anaconda, Kennecott and Cerro to create the state-owned enterprise CODELCO, a few years before significant increases in copper prices. Later, in 1972, he expropriated ITT after discovering that the firm was involved in a scheme to overthrow him. It is worth highlighting that, despite the fierce opposition Allende faced from the Chilean center and right-wing parties, these two initiatives passed smoothly in the Chilean parliament. ${ }^{52}$ Resource nationalism permitted Allende to have a wider agenda regarding expropriation in this particular industry than the one he could count on for other policies. 
The examples in this section discuss cases of countries that undergo social, economic, and political transformations. This leads to a change from a regime supported by a small elite alliance that included the foreign investors to one that relies on a wider political alliance that includes the middle and lower classes (the latter usually participating in politics through powerful labor unions). To reward the members of their political alliance and ensure their loyalty, governments of both left-leaning and centerright leaning orientation often took over the properties of foreign firms to establish jobcreating state-owned enterprises and invest in areas of interest for their political alliance. ${ }^{53}$ All these initiatives were supported by rhetoric that fused economic independence and national sovereignty. Although an alliance with organized labor was an important factor, in making these expropriations possible, they did not necessarily translate into an increase of the welfare in general. Throughout the decades following the expropriations, the labor unions of both PDVSA and PEMEX were notorious for their corruption. In the Chilean case, the copper industry continued to be one of the main sources of income for the military, so it was not re-privatized.

\section{Government Alliances With Domestic Business Sector}

Even though one would assume that the domestic private sector should oppose expropriation of foreign property on the grounds that domestic firms would see this action as a threat to their property rights, several scholars argue that a government can selectively protect property rights -ensuring that the property of a particular group will not be subject to expropriation. ${ }^{54}$ This is most likely where domestic business has 
significant political influence. When a government's main constituency is composed of domestic businesspeople in societies that offer limited political participation for the wider population, a government might either increase taxation on foreign firms or expropriate foreign property to redistribute rents among a segment of the private sector. Two West African cases highlight how expropriation via indigenization decrees aimed to legitimize the postcolonial national identity and citizenship. ${ }^{55}$

The policies followed by the government of Ghana after independence in 1957 highlight the role of the domestic business community in the expropriation of foreign property. Ghana, the first British Sub-Saharan colony to gain independence, began expropriations after its first head of state (Kwame Nkrumah) was overthrown in 1966 by an alliance of pro-Western police and military men. As a result of this turbulent political history, the expropriation programs fall into two distinct periods: an early phase from 1968 to 1969 and a later phase from 1972 to 1977 . The "caretaker" regime that overthrew Nkrumah in 1966 returned the country to a short-lived democracy in 1969, which ended in 1972 after General Ignatius Acheampong and the military overthrew the government. In terms of the expropriation programs, the earlier decrees were minor and focused on resident foreigners, such as the Lebanese community. These were not foreign investors as understood in international business scholarship. The targeted groups were, rather, domestic investors with foreign nationalities. The fact that these groups were frequently the most affected by indigenization legislation suggests that these forms of expropriations were closely intertwined with contemporary struggles over citizenship in postcolonial Africa. ${ }^{56}$ Major beneficiaries of the indigenization legislation were small African businesses, which had felt threatened by the competition. ${ }^{57}$ 
A somewhat different pattern emerges from Ghanaian expropriations after 1972, both regarding the motivations behind these policies as well as the firms that they targeted. In 1972, the partial nationalization of privately-owned gold mines was announced; compensation for the 55 percent stake was negotiated by 1974 . In other sectors, the government opted for indigenization instead of nationalization, which amounted to the forced sale of foreign business to domestic citizens, rather than the government. Similar to the indigenization decree of the late 1960s, this measure mostly targeted companies owned by resident Lebanese traders. Politically significant groups such as small shopkeepers and market traders supported these decrees. But the 1970s program went further and also legislated the partial indigenization of large, Westernowned businesses. ${ }^{58}$ The main beneficiaries were relatively wealthy investors, as well as skilled employees and Ghanaian managers, who gained access both to lucrative investment and better positions in foreign companies. As this was mostly achieved through the sale of shares, foreign investors remained the main shareholders. Targeted nationalization, as in the case of gold mining, aimed to more strategically expand government control over the main sources of foreign exchange income.

The most consistent pressure, however, was applied to companies regarding their employment practices, suggesting a desire to open up more opportunities to bettereducated members of the middle class, who left the country in large numbers in the 1970s to find a better life abroad, given the declining economy and the repressive political regime. Expatriate immigration quotas had been in place since the days of Nkrumah's rule (1957-1966), but they became increasingly restrictive. Foreign firms were now at pains to show that they hired, trained, and promoted Ghanaians into responsible 
positions. ${ }^{59}$ This suggests an attempt on the part of the military government to gain the support of a relatively broad section of the population: predominantly urban, the alliance included groups such as uneducated owners of small shops, owners of medium-sized enterprises, well-educated, salaried or professional middle classes and relatively wealthy investors. Organized labor was noticeably absent here, even though it played a more significant part in the Latin American cases. In post-colonial Africa, trade unions had become dominated by political parties and only rarely found an independent voice or had the power to influence politics. ${ }^{60}$

The Nigerian expropriations of the 1970s share some similarities with those of Ghana but in a context of greater political instability and booming oil prices. After the country became independent in 1960, it adopted a federal democratic system, plagued from the outset by regional rivalries and political tensions. The discovery of major oil and petroleum deposits in the Niger Delta in the late 1960s influenced the political landscape of the independent country, and, in what came to be known as the "resource curse," further undermined effective governance ${ }^{61}$ In 1966, Nigeria's government was overthrown in a military coup, and ethnic tensions between the different regions led to the secession of Eastern Nigeria under the name of Biafra. The ensuing civil war lasted from 1967 to 1970, and the control of the oil-producing areas in the Niger Delta was key to the conflict. The willingness of international oil producers to collaborate with the Biafrans undermined their legitimacy in the eyes of the Nigerian government.

At the end of the Nigerian civil war, the government partly nationalized the three largest commercial banks, which were all foreign-owned. This was a strategic decision to ensure access to finance for the subsequent indigenization decrees. In 1972, the first 
Nigerian Enterprise Promotion Decree (NEPD 1) favored domestic business owners similar to indigenization in Ghana, but targeted not just small to medium-sized companies but also larger international ones. The government negotiated separately with the oil companies over partial expropriations. ${ }^{62}$ In 1975 , Olusegun Obasanjo took over the military government and his administration were critical of what NEPD 1 had achieved so far. NEPD 2 was announced in 1977 and aimed to be far more comprehensive than its predecessor. However, its implementation coincided with a slump in oil prices and general turmoil in the international economy, as several developing countries faced a debt crisis. In 1981, the Nigerian government reclassified several industries to attract foreign investment, effectively reversing many of the decisions of NEPD $2 .{ }^{63}$ Falling oil prices curbed the political and economic gains that could be realized from expropriating existing foreign investment and increasingly limited the inflow of new international investment. ${ }^{64}$ However, while prices fell from their peak in 1980, they never dropped below the already high level reached in 1973.

The NEPDs was shaped partly by the demands of Nigerian businesspeople, who effectively lobbied the government, especially for NEPD $1 .{ }^{65}$ Local business owners stood to gain the most from expropriating Lebanese and Western small to medium-sized enterprises, and from being able to gain a stake in major Western multinationals. ${ }^{66}$ Subsequently, public criticisms of NEPD 1 focused on redistributive issues, especially the highly oversubscribed public issues that led to the concentration of wealth in the hands of a few already affluent individuals and families, with around twenty individuals or family groups taking up the majority of the shares according to some estimates. ${ }^{67}$ 
NEPD 2 showed greater control by the state bureaucracy but was too short-lived to achieve its aims fully.

These two cases evidence some of the conditions under which the domestic private sector of a country can choose to support the expropriation of foreign private property. In both cases, domestic businesspeople lobbied military governments in the name of economic decolonization and better domestic development. ${ }^{68}$ Even though some sub-Saharan rulers gravitated towards the Soviet Union during the Cold War, this was not the case for Nigeria or Ghana after Nkrumah. Expropriations in these countries did not necessarily amount to hostility towards the private sector, they were, rather, a form of economic nationalism and were driven by domestic political concerns and volatile commodity prices, rather than ideological commitments. In countries where selfemployment was more common than unionized employment, small domestic businesses sought government support against foreign competitors. The better-educated middle classes wanted improved employment opportunities by lobbying for reducing the number of expatriates holding senior posts. This created a political constituency in favor of expropriating foreign investors. However, these groups preferred indigenization over nationalization, which offered direct benefit in terms of investment and employment.

\section{Government Alliance With State Bureaucracy}

While indigenization was a common form of expropriation in West Africa, East African countries were more likely to opt for nationalization. We assume that the governments of host countries do not necessarily act as a homogenous entity, and 
consider instead how they are subjected to power struggles between different interest groups. In African countries, many of which were one-party states, intra-party competition was of particular relevance. In this section, we examine cases in which the expropriation of foreign property was a measure through which a government sought to maintain the support of party members or senior administrators. The history of expropriations in Tanzania and Zambia are instructive here because both countries experimented with different types of "African socialism" and both had stable and longterm autocratic regimes.

Tanzania’s long-term ruler Julius Nyerere (1961-1985) provides a case in which a government undertook the most comprehensive attempt to convert "African Socialism" into reality through a national scheme of village collectivization known as Ujamaa, which initially aimed to redistribute assets and services to small-scale collectives. ${ }^{69}$ Nyerere announced the Arusha Declaration in 1967 because he had grown concerned at the power wielded by members of his party and the wider government bureaucracy. As party members were unsurprisingly not enthused by a program partly designed to curb their influence and control over resources, Nyerere sought to gain their support when he "announced a series of nationalizations that were guaranteed to garner public sympathy."70 These policies played well with a long-standing anti-foreign undercurrent within the party, as they most affected resident ethnic Asian and European businesspeople, similarly to the targeting of Lebanese businesspeople in West Africa. Here, public enthusiasm was employed as a kind of "psychic gain" to camouflage other less popular measures, as argued by Albert Breton for the Canadian case. ${ }^{71}$ 
The political alliance driving these policies was different from both the nationalizations in Latin America and the West African cases of expropriation. Neither labor nor domestic business was economically or politically strong enough to drive major changes in economic policies. Power was centralized in the one-party state, i.e., Tanganyika African National Union (TANU) and the government administration. Civil servants had been prevented by colonial rules to join TANU and were generally better educated, Western-oriented, and focused on technocratic solutions to improve economic growth. TANU officials excelled through their political commitment to a left-leaning party, favored redistributive economic policies, and lacked the skills and expertise to exercise effective control of the civil service. ${ }^{72}$ Support for nationalization came mainly from party officials, while civil servants were concerned about capital flight and a reduction in tax revenue.

Tanzania was heavily agricultural, lacked substantial industries and opportunities for continued economic development were constrained without foreign capital, which dominated the economy. This was particularly obvious in finance and banking, and also industrial production. When the nationalization of the banks and insurance were announced, most of their finance was invested in London, out of reach of the Tanzanian government. After the Arusha declaration, the state took over the banks, the National Insurance Corporation, flour-milling firms, as well as controlling interests in seven industries, sisal production, and trading companies. ${ }^{73}$ While the banks and other firms were in a relatively strong bargaining position as they had relatively less capital in Tanzania at the time of nationalization, nationalizations remained popular with party leaders. They continued to press for more expropriations, and in 1970 Nyerere announced 
the nationalization of wholesale trade and private import-export firms, mostly controlled by Asians. This follows a familiar pattern to West African indigenization programs targeting Lebanese to a significant extent. In 1976, "Operation Maduka" extended this to retail in Tanzania, seeking to replace small Asian-owned retail shops and replacing them with co-operatives. ${ }^{74}$

These policies were popular because they opened up employment opportunities in the commercial sector, as well as facilitating rapid promotion to management positions in the subsidiaries of international companies such as the banks. ${ }^{75}$ The political importance of Africanization in Tanzania is shown by Nyerere's 1964 attempt to abolish it on the grounds of racial discrimination. The army responded by an abortive military coup, which strengthened the hands of party officials who successfully pressed for the Arusha declaration of $1967 .{ }^{76}$ While socialist ideology in the form of "controlling the heights of the economy" and self-reliant national economic development became institutionalized from the late 1960s onwards, Tanzanian nationalization reflected domestic political alliances not necessarily based on socialist ideology. Party officials sought the support of the electorate by opening up employment opportunities through nationalization, whereas civil servants' interests were, in general, aligned with foreign investors as they sought the capital for development initiatives.

By the late 1970s, economic crisis engulfed Tanzania: between 1978 and 1985, manufacturing declined from 13.5 to 6.9 percent of the GDP, which also shrank in that period. While the country maintained democratic elections throughout that time, the elected parliament was fairly powerless, as a small alliance of bureaucrats and party members retained significant influence. ${ }^{77}$ Although Nyerere's approach to nationalization 
was populist and aimed at gaining the support of a larger alliance within his party and beyond, it ultimately mostly benefitted a narrow alliance of mainly party members and some civil servants, who directly controlled the assets of foreign firms. ${ }^{78}$

The Zambian expropriations highlight a similar strategy of seeking to ensure the continued support of different groups of government officials during the tenure of Kenneth Kaunda, who led the United National Independence Party, UNIP (1964-1991). The nationalizations of the copper mining companies in Zambia received a significant amount of attention in the general media and scholarly literature (similarly to the nationalization of copper mining in Chile). ${ }^{79}$ Zambia's economy and government were highly dependent on the performance of this notoriously cyclical industry. ${ }^{80}$ Although other privately owned companies operating in Zambia, many were either resident expatriate or foreign-owned and were significantly smaller than the copper companies. Zambian-owned enterprises were limited, as they had been restricted from trading during the colonial period. The National Wholesale and Marketing Company was in part a vehicle to support the expansion of private Zambian business, but progress was perceived as too slow. ${ }^{81}$ As part of the government's decision to "localize" the economy, in 1968 and 1969 Kaunda requested partial nationalization of foreign firms in return for adequate compensation. At the same time, several parastatal organizations (state-owned enterprises) were created to oversee the performance of the public-private joint ventures, in line with ideas of African socialism. These parastatals wielded significant political influence, led by Zambians such as Andrew Sardanis at INDECO. Even though they were not technically part of the administration, they were effectively controlled by the government. ${ }^{82}$ Parastatals were staffed by well-educated, younger professionals, often 
referred to as "technocrats" for whom there were no obvious openings in the civil service and the party ranks, and who were paid higher salaries in the parastatals than could be achieved in the regular civil service. ${ }^{83}$

With a surprise announcement in 1973, the Zambian government fully nationalized the two copper mining joint ventures ahead of significant increases in copper prices. But even more significantly for their domestic alliances, they placed the supervision of mining under two ministries, thus reassigning a function that was previously performed by a parastatal. Civil servants asserted control over nationalized companies, at the expense of the technocrats leading parastatals. While organized labor was a significant constituency in the Copperbelt, the union remained relatively unpolitical, and strikes were banned by the Zambian government in this period. More significant were divergent interests within the state that crystallized around three groups: politicians, civil servants, and technocrats. Similar to Tanzania, the politicians were less well educated than the civil servants and the technocrats, while the civil servants were established in top ministerial posts. As the pace of promotion slowed down with the near completion of the Africanization process from which the civil servants had benefitted, the relatively younger group of technocrats had fewer opportunities. ${ }^{84}$ Nationalization opened up well-paid positions in the parastatals for technocrats and some entrepreneurs, which created conflict with less well-paid civil servants. Earlier nationalizations also increased the influence of technocrats like Sardanis, leading to conflict with politicians and civil servants. The technocrats had dominated the earlier partial nationalization, while the later expropriations were prompted by further internal political divisions within the government. ${ }^{85}$ Similarly to the nationalizations in Tanzania, the Zambian 
nationalizations were driven by quite a narrow constituency within the public sector that, despite its limited scope, experienced internal competition between different groups of party members and civil servants, most notably the younger generation of technocrats and the civil servants in charge of ministries.

\section{A new framework for understanding expropriation}

Business historians have studied economic nationalism, expropriations, and their impact on companies extensively. ${ }^{86}$ However, many other disciplines have been more influential in putting forward general explanations of why countries would seek to expropriate, which we review in the next section. ${ }^{87}$ This is partly because the research questions that business historians have asked differ significantly from those in international business or political economy. Historians have been more interested in why some governments expropriate while others do not under similar circumstances, how they choose to implement expropriation, and who ultimately benefits from expropriations. It is nevertheless more difficult to generalize from a diverse set of individual in-depth case studies that span different continents and periods, and this has limited the influence of historical research on the wider debate. This is why we believe that a more historiographical approach that synthesizes existing historical research has the potential to offer new insights to historical as well as interdisciplinary researchers.

Historiography summarizes historical controversies that often focus on similar research questions, or the same historical event, period, or topic. This is not the case for historical research on expropriations, which often asks different research questions while 
focusing on different countries and periods. Hence, we engaged with debates on comparative historiography, but focus on how narrative synthesis can be useful to business history in generating frameworks to understand and compare in-depth historical cases. The necessity to draw on the existing historical research more synthetically was already recognized in the 1950s and gained greater traction in the 1980s as comparative history. ${ }^{88}$ More recently, the notion of comparative historiography has come to the fore again, but mostly as comparative work on the nature of historical writing in different cultures, rather than the more empirical approach which we develop here. ${ }^{89}$

In our synthesis, we first focus on the role of economic nationalism in establishing the historical legitimacy of the nation-state. Historians maintain that the legitimacy of a nation-state is built on a series of widely accepted myths around the country's creation and general characteristics often promoted from above through "conscious and deliberate ideological engineering." ${ }^{90}$ National movements often gained independence from their former colonial metropoles without military conflict when they formed "newly emancipated states claiming a national identity which they did not possess.." ${ }^{\prime 1}$ Defining a national identity within new territorial borders inhabited by diverse cultural and ethnic groups posed distinct challenges. Elites in "peripheral countries" (meaning those not belonging to Western Europe, United States and other areas of the rich world) face the problem of trying to generate national pride in countries that are poor and subordinated to the world powers.

One way in which those elites dealt with this challenge consisted of in promoting unity and a sense of belonging to a nation-state by romanticizing their country's peripheral status and promoting a sentiment of pride around the perceived necessity of 
"resistance" against exploitative imperialism. ${ }^{92}$ Persistent poverty means that peripheral elites struggled to generate national pride around non-material issues. Therefore, developing countries whose economies were dominated by the export of one or two natural resources created a sense of national belonging around narratives in which those exports represented the promise of future economic development and stability. ${ }^{93}$ Countries with these characteristics often developed nationalism around a sense of collective ownership of a natural resource, or other economic activities considered a feature of national identity. ${ }^{94}$

The population of a peripheral country can make common cause around the defense of domestic control or ownership of their export products or main economic activity. For instance, from the 1960s to the 2000s, different Latin American governments used the same slogan when expropriating foreign oil: "the oil is ours." 95 In a discussion of Canadian economic nationalism, Breton argued that this populist rhetoric resulted in an intangible "psychic gain." ${ }^{" 96}$ Our analysis of the expropriation of foreign property engages with these theoretical approaches to peripheral economies by taking into consideration both the challenges of building a nation-state in the twentieth century as well as the mobilization of the population around the fate of an export product or key economic sector under foreign control.

Thus the longevity of the nation-state is a crucial element to understand expropriations of foreign private property. Nation-states had already consolidated when major expropriations took place in Latin America, whereas in Sub-Saharan Africa, they had not. Latin American nation-states emerged between the 1820s and the 1870s. During this period, most Latin American countries went from being part of the Spanish Empire 
to having their national borders defined in a way that does not differ much from those we find in the early twenty-first century. This means that by the early twentieth century, most Latin American states had developed some administrative capacity and no longer faced contestations regarding who belonged to the national community and had citizen's rights. By the early twentieth century, few Latin Americans challenged the idea that their national identity included European elements such as the Spanish and Portuguese languages or the Catholic faith. Most post-1920s social conflicts in Latin America were defined by class struggles rather than by national identity, with the labor movement playing an increasingly important role in the evolution of political parties. ${ }^{97}$

In sub-Saharan Africa, expropriations took place after the 1960s, when those countries were experiencing a process of postcolonial state-formation with the attendant need to legitimize these new political units. During this period, these countries were still defining what it meant to be a national citizen and, in determining this status, granted increased importance to ethnic origin over the place of birth or residence. ${ }^{98}$ Most African states emerged out of colonial administrative units, which reflected international diplomacy and a pattern of exploration and subjugation that bore little similarity with preexisting political, ethnic, or social divisions. ${ }^{99}$ There were few cases of territorial states in Africa before colonial expansion in the nineteenth century. Thus, the colonial languages were frequently the only languages spoken jointly, although in East Africa Kiswahili was significant, and elsewhere European languages were localized as Krio/Creole and Pidgin. The majority of former British, Belgian, and French colonies gained independence in the 1960s, for the most part in a relatively orderly process of constitutional devolution. ${ }^{100}$ 
African nationalists were frequently co-opted by colonial administrations during decolonization (with some important exceptions). ${ }^{101}$

\section{Insert Table 2 about here}

The features of expropriation policies in sub-Saharan Africa should be viewed in this context (for a summary, see Table 2). Expropriation policies did not just reflect attempts on the part of governments to create political alliances; they also aimed to enhance the fundamental institutional legitimacy of the state itself. ${ }^{102}$ The state needed to provide opportunities and income to its most important constituencies, especially the urban and educated population.

A second significant element defining the composition of the alliances is the strength of labor unions. By the 1920s and 1930s, labor unions in many Latin American countries played an important political role and employed nationalist rhetoric.

Conversely, labor unions did not play a significant role in most sub-Saharan African countries after independence. Unions and independent African governments had an often complicated relationship (in some cases, like in Zambia, this was because white workers dominated the unions). ${ }^{103}$ In other cases, young professionals working for foreign firms did not always see unions as the best means of advancing within these firms, especially as the unions were either fractured or controlled by the ruling party and thus deeply politicized. ${ }^{104}$

A final factor is the presence of a sizeable number of domestic business people with effective political representation. In the West African cases, the political influence 
of small urban market traders was comparable to that of the labor unions in Latin America, but of a different nature. Moreover, politically influential elite families also sought to protect or extend their business interests. For the East African cases, these groups were relatively weak and politically marginalized. In most Latin American countries, domestic business owners were closely associated with the government, but during periods of populist rule, they were on the defensive. ${ }^{105}$ As we show below, however, they could, on occasion, be part of a political alliance against foreign capital if they perceived that economic benefits could ensue from that action.

We explain how governments in Latin America and sub-Saharan Africa sought the support of different groups of political supporters by drawing on selectorate theory, which focuses on the mechanisms of political survival. ${ }^{106}$ This theory assumes that all types of governments (whether they are elected officials or dictators) will need to respond to a specific constituency. ${ }^{107}$ Even the most openly dictatorial regimes are aware of the need to secure the loyalty of a mass of people to whom they offer economic benefits and not simply out of fear. ${ }^{108}$ Similarly, elected officials seeking to secure their re-election or that of their political party may engage in the political game to ensure the loyalty of this alliance that will mobilize voters to the polls. Thus, these scholars maintain that the main goal of economic policy (in either authoritarian regimes or pluralistic ones) is to ensure the political survival of those in power (either an individual, a military junta, or a political party). This means that, when necessary, a country's rulers will follow economic policies that ensure the loyalty of their alliance even if those policies go against their official ideology or do not translate into more growth or efficiency. ${ }^{109}$ We refer to this as “political alliance." If the rulers' survival depends on a relatively small political alliance 
(say a few generals, some families, or a particular ethnic group), they will develop economic policies that particularly benefit the members of that group. Conversely, if government's survival depends on a large-scale political alliance (e.g., voters of a particular party, large labor unions, a large revolutionary army, or even a large ethnic group), economic policy would seek to distribute economic rents among that large number of members that make up this political alliance.

From our comparative case histories, we conclude that the interplay between these two factors - nationalism and political alliances - determined decisions to expropriate, often in conjunction with the movement of international prices for commodities controlled by expropriated firms. When general conditions were favorable for expropriation, it became attractive for governments in developing countries to gain political support through economic nationalism. While many countries expropriated foreign investors in the middle of the twentieth century, by no means, all developing countries did so. Economic nationalism became an important factor if the longevity and legitimacy of the nation-state were key political issues that would mobilize political support. For West Africa, Collins and Biersteker, for example, highlighted that domestic redistribution struggles drove expropriations. ${ }^{110}$ Wilson argued that country studies alone did not reflect how nationalization and indigenization in Africa were driven by the relative economic and political influence of the domestic business (broadly seen as favoring indigenization) and bureaucrats (favoring nationalization). ${ }^{111}$

By generalizing at this level, we do not want to downplay either the diversity of these two continents or the complexity of their political and economic histories. We believe that studies investigating the types of political alliances could be extended to 
other countries and periods. By focusing the explanation on central analytical issues such as the longevity of the nation-state and the political influence of specific domestic constituencies, we construct a broad explanatory framework that allows business historians to compare different cases of expropriation across time and space.

\section{Conclusion}

This paper proposes a model of alliances that support the expropriation of foreign private property in developing countries. We demonstrate how different types of expropriations correspond to strategies for political survival in which rulers need to ensure the support of their constituency. We categorize these alliances according to which stakeholders were mobilized around the government expropriation policies, who had a significant influence on the ultimate design of expropriation decrees, or expected rewards from the expropriation: labor unions, domestic businesses, or the public servants. Our categorization takes into account the legitimacy and longevity of the nation-state and the political importance of organized labor or domestic business. Our research complements other studies that have focused on technological and host country institutional characteristics of the industry and the impact of the evolution of international commodity prices. We extend and integrate these insights by comparing the African cases with Latin America, which highlights another dynamic, that between labor, party politics, and domestic business. This needs to be understood in terms of how economically developed these countries are, and how clearly defined and secure the concept of national identity and the nation-state is. We are aware that the type of alliances defined in this paper are 
not the only possible ones, but we hope this paper will open the door for other scholars to define other types of coalitions governments build around expropriation policies. 
References

Books

Akinsanya, Adeoye A. The Expropriation of Multinational Property in the Third World. New York: Praeger, 1980.

Bates, Robert H. Markets and States in Tropical Africa: The Political Basis of Agricultural Policies. Berkeley: University of California Press, 1981.

Bayart, Jean-François. The State in Africa: The Politics of the Belly. London: Wiley, 1993.

Beckman, Ericka. Capital Fictions: The Literature of Latin America's Export Age. Minneapolis: University of Minnesota Press, 2013.

Bermúdez Romero, Manuel. PDVSA en carne propia: testimonio del derrumbe de la primera empresa venezolana. Caracas: OME, 2008.

Biersteker, Thomas J. Multinationals, the State, and the Control of the Nigerian Economy. Princeton: Princeton University Press, 1987.

Butler, Larry J. Copper Empire: Mining and the Colonial State in Northern Rhodesia, c. 1930-64. Cambridge Imperial and Post-Colonial Studies. Houndmill: Palgrave Macmillan, 2007.

Bueno de Mesquita, Bruce, Alastair Smith, Randolph Siverson, and James Morrow. The Logic of Political Survival. Cambridge: MIT Press.

Burawoy, Michael. The Color of Class in Copper Mines: From African Advancements to Zambianization. Manchester: Manchester University Press, 1972. 
Butler, Larry. "Mining, Nationalism, and Decolonization in Zambia Interpreting Business Responses to Political Change, 1945-1964.” Archiv Für Sozialgeschichte No. 1, 48 (2008): 1-17.

Butler, Larry. Copper Empire: Mining and the Colonial State in Northern Rhodesia, $c$. 1930-1964. Houndmill: Palgrave, 2007.

Butler, Larry. Copper Empire: Mining and the Colonial State in Northern Rhodesia, $c$. 1930-64. Houndmill: Palgrave, 2007.

Ceresole, Norberto. Perú o el nascimiento del sistema latinoamericano. Buenos Aires: Galerna, 1971.

Cooper, Frederick. Africa since 1940: The Past of the Present. Cambridge: University Press, 2002.

Cooper, Frederick. Decolonization and African Society: The Labor Question in French and British Africa. Cambridge: Cambridge University Press, 1996.

DiJohn, Jonathan. From Windfall to Curse? Oil and Industrialization in Venezuela, 1920 to the Present. University Park: Pennsylvania State University Press, 2009.

Dos Santos, Theotonio. Imperialismo y dependencia. Mexico City: Era, 1978.

Eggerston, Thráinn. Imperfect Institutions: Possibilities and Limits of Reform. Ann Arbor: University of Michigan Press, 2005.

Evans, Peter. Dependent Development: The Alliance of Multinational, State, and Local Capital in Brazil. Princeton: Princeton University Press, 1979.

Fieldhouse, David K. Economic Decolonisation and Arrested Development. Black Africa 1945-1980. London: Allen \& Unwin, 1986. 
Fieldhouse, David K. Merchant Capital and Economic Decolonisation: The United Africa Company 1929-1987. Oxford: Clarendon, 1994.

Forrest, Tom. The Advance of African Capital: The Growth of Nigerian Private Enterprise. Charlottesville: University of Virginia Press, 1994.

Freund, Bill. The African Worker. Cambridge: Cambridge University Press, 1988.

Garner, Paul. British Lions and Mexican Eagles: Business, Politics, and Empire in the Career of Weetman Pearson in Mexico1889-1919. Stanford: Stanford University Press, 2011.

Gough, D, S Oliver, and J Thomas. An Introduction to Systematic Reviews. Thousand Oaks CA: Sage, 2017.

Haber, Stephen, Armando Razo, and Noel Maurer. The Politics of Property Rights: Political Instability, Credible Commitments, and Economic Growth in Mexico, 1876-1929. Cambridge: Cambridge University Press, 2003.

Hobsbawm, Eric. Nations and Nationalism Since 1780. Cambridge: Cambridge University Press, 1990.

Holland, Robert. European Decolonization, 1918-1981: An Introductory Survey. London: Macmillan, 1985.

Jensen, Nathan. Nation States and the Multinational Corporation. Princeton: Princeton University Press, 2006.

Jones, Geoffrey and Stephanie Decker. Unilever as a "Multi-Local” Multinational 19451979. Harvard Business School Teaching Case No. 808-025. Boston: Harvard Business School, 2007.

Lipson, Charles. Standing Guard: Protecting Foreign Capitalism in the Nineteenth and 
Twentieth Century. Berkeley and London: University of California Press, 1985. Maurer, Noel. The Empire Trap: The Rise and Fall of U.S. Intervention to Protect American Property Overseas, 1893-2013. Princeton: Princeton University Press, 2013.

McBeth, Brian. La política petrolera venezolana: una perspectiva histórica, 1922-2005. Caracas: Universidad Metropolitana, 2015.

Moran, Theodore. Multinational Corporations and the Politics of Dependence: Copper in Chile. Princeton: Princeton University Press, 1974.

Nkrumah, Kwame. Neo-Colonialism: The Last Stage of Imperialism. New York: International Publishers, 1965.

Noblit, George W., and R. Dwight Hare. Meta-Ethnography: Synthesizing Qualitative Studies. Qualitative Research Methods Series Newbury Park. Vol. 11. Thousand Oaks CA: Sage Publications, 1988.

North, Douglass. Institutions, Institutional Change, and Economic Performance. Cambridge: Cambridge University Press, 1990.

Nugent, Paul. Africa since Independence. Basingstoke: Palgrave, 2002.

Patiño, Ninfa. El discurso de los políticos frente al otro. Quito: Abya Yala, 1996.

Rodríguez González, Guillermo. En mala compañía. Caracas: Tercer Polo, 2006.

Schneider, Ben Ross. Business Politics and the State in Twentieth-Century Latin America. Cambridge: Cambridge University Press, 2005.

Sardanis, Andrew. A Venture in Africa: The Challenges of African Business. London and New York: I.B. Tauris, 2007. 
Schultz, Helga and Eduard Kubu (eds.). History and Culture of Economic Nationalism in East Central Europe. Berlin: Berliner Wissenschafts-Verlag GmbH, 2006.

Scott, James C. Seeing like a State: How Certain Schemes to Improve the Human Condition Have Failed. New Haven: Yale University Press, 1998.

Sigmund, Paul E. Multinationals in Latin America: The Politics of Nationalization, A Twentieth Century Fund Study (Madison: University of Wisconsin Press, 1980).

Sklar, Richard. Corporate Power in an African State: The Political Impact of Multinational Mining Companies in Zambia. Berkeley: University of California Press, 1975.

Stockwell, Sarah E. The Business of Decolonization: British Business Strategies in the Gold Coast. Oxford: Clarendon Press, 2000.

Tugwell, Franklin. The Politics of Oil in Venezuela. Stanford: Stanford University Press, 1975.

Vernon, Raymond. Sovereignty at Bay (New York: Basic Books, 1971).

Wellhausen, Rachel. The Shield of Nationality: When Governments Break Contracts With Foreign Firms. Cambridge: Cambridge University Press, 2015.

Wells, Louis and Rafiq Ahmed. Making Foreign Investment Safe: Property Rights and National Sovereignty. Oxford: Oxford University Press, 2007.

White, Nicholas J. British Business in Post-Colonial Malaysia, 1957 -70: NeoColonialism or Disengagement?. London: Routledge, 2004.

Wilkins, Mira. The Maturing of Multinational Enterprise: American Business Abroad, 1914-1970. Cambridge, MA: Harvard University Press, 1974. 
Yin, Robert K. Case Study Research: Design and Methods. Thousand Oaks, CA, and London: Sage, 2003.

Articles

“Argentina a Repsol y su filial YPF,” El País April 17 (2012), URL:

http://economia.elpais.com/economia/2012/04/16/actualidad/1334590509_507539 .html (accessed December 2 2016).

"Venezuela nacionaliza a Monaca," BBC Mundo (May 14, 2010), URL:

http://www.bbc.com/mundo/economia/2010/05/100513_0217_venezuela_naciona liza_monaca_lf.shtml).

Abdelrehim, Neveen, and Steven Toms. "The Obsolescing Bargain Model and Oil: The Anglo-Iranian Oil Company 1933-1951.” Business History 59, no. 4 (2017): 55471.

Afrifa Taylor, Ayowa. "An Economic History of the Ashanti Goldfields Corporation, 1895-2004: Land, Labour, Capital and Enterprise." Department of Economic History, London School of Economics and Political Science, 2006.

Akinsanya, Adeoye. "International protection of direct foreign investments in the third world." International and Comparative Law Quarterly, 36, No. 1 (1987): 58-75.

Aminzade, Ronald. "The Dialectic of Nation Building in Postcolonial Tanzania." Sociological Quarterly 54, no. 3 (2013): 335-66. 
Barret, Richard. "Avoiding the Expropriation Nightmare: Tax Consequences and Asset Protection Techniques." University of Miami Law Review, 52, no. 3 (1998): 831854.

Breton, Albert. "The Economics of Nationalism," The Journal of Political Economy 72, no. 4 (1964): 376-86

Brown, Jonathan. "Why Foreign Oil Companies Shifted Their Production from Mexico to Venezuela During the 1920s." American Historical Review 90, No. 2 (1995): $362-385$.

Brown, Jonathan. Oil and Revolution in Mexico. Berkeley: University of California Press, 1993.

Bucheli, Marcelo. "Canadian Multinational Corporations and Economic Nationalism: The Case of Imperial Oil Limited in Alberta (Canada) and Colombia, 18991938." Entreprises et Histoire 54, no. April (2010): 67-85.

Bucheli, Marcelo. "Multinational Corporations, Totalitarian Regimes and Economic Nationalism: United Fruit Company in Central America, 1899-1975.” Business History 50, no. 4 (2008): 433-54.

Bucheli, Marcelo, and Ruth V. Aguilera. "Political Survival, Energy Policies, and Multinational Corporations: A Historical Study for Standard Oil of New Jersey in Colombia, Mexico, and Venezuela in the Twentieth Century." Management International Review 50, no. 3 (2010): 347-78.

Bucheli, Marcelo and Jin Uk Kim. "The State as a Historical Construct in Organization Studies." In Organizations in Time: History, Theory, Methods, edited by Marcelo 
Bucheli and R. Daniel Wadhwani, 241-262. Oxford: Oxford University Press, 2014.

Bucheli, Marcelo and Minyoung Kim. “Attacked from Both Sides: A Dynamic Model of Multinational Corporations' Strategies for Protection of Their Property Rights.” Global Strategy Journal 5, No. 1 (2015): 1-26

Bucheli, Marcelo, and Erica Salvaj. "Multinational Corporations' Obsolescing Political Legitimacy: ITT in Chile, 1920-1972.” Business History Review 87, no. 3 (2013): 729-55.

Burdette, Marcia. "Nationalization in Zambia: A Critique of Bargaining Theory." Canadian Journal of African Studies 11, No. 3 (1977): 471-496.

Burto, F. N and Hisashi Inoue, "Expropriations of Foreign-Owned Firms in Developing Countries: A Cross-National Analysis,” Journal of World Trade Law, 396 (1984): 396-414.

Collins, Paul. "The Political Economy of Indigenization: The Case of the Nigerian Enterprises Promotion Decree.” African Review 4, no. 4 (1974): 491-508.

Darwin, John. "Decolonization and the End of Empire." In The Oxford History of the British Empire, edited by Robin Winks, 541-57. Oxford: Oxford University Press, 1999.

Decker, Stephanie. "Building up Goodwill: British Business, Development and Economic Nationalism in Ghana and Nigeria, 1945-1977.” Enterprise and Society 9, no. 4 (2008): 602-13. 
Decker, Stephanie. "Corporate Legitimacy and Advertising: British Companies and the Rhetoric of Development in West Africa, 1950-1970.” Business History Review 81, no. 1 (2007): 59-86.

Decker, Stephanie. "Dekolonisation Der Wirtschaft?: Wirtschaftsnationalismus in Afrika Nach 1945." Archiv Für Sozialgeschichte 48 (2008): 461-86.

Decker, Stephanie. "Postcolonial Transitions in Africa: Decolonization in West Africa and Present Day South Africa," Journal of Management Studies 47, no. 5 (2010): 791-813.

Decker, Stephanie. "The emergence of Africanization as a legitimization strategy for British multinationals in Ghana and Nigeria 1945-1970." Business History Review 92, no. 4 (2018): 691-718.

Dos Santos, Theotonio. "The structure of dependence," American Economic Review 60, no. 2 (1970): 231-236.

Duncan, Roderick. "Price or politics? An Investigation of the Causes of Expropriation," The Australian Journal of Agricultural and Resource Economics, 50, No. 1 (2006): 85-101.

Durán, Xavier and Marcelo Bucheli. "Holding Up the Empire: Colombia, American Oil Interests, and the 1921 Urrutia-Thomson Treaty.” Journal of Economic History, 77, No. 1 (2017): 251-284.

Elkins, Zach, Guzmán, Andrew, and Simmons, Beth. "Competing for Capital: The Diffusion of Bilateral Investment Treaties, 1960-2000. International Organization, 60 No. 4 (2006): 811-846. 
Ellner, Steve. "Trade Union Autonomy and the Emergence of a New Labor Movement in Venezuela." In Venezuela: Hugo Chávez and the Decline of an "Exceptional Democracy" edited by Steve Ellner and Miguel Tinker Salas. New York: Rowman and Littlefield, 2007.

Englebert, Pierre. "Pre-Colonial Institutions, Post-Colonial States, and Economic Development in Tropical Africa." Political Research Quarterly, 53, No. 1 (2000): 7-36

Esseks, John D. “Economic Policies.” In Politicians and Soldiers in Ghana 1966-1972, edited by Dennis Austin and Robin Luckham. London: Frank Cass, 1975.

Genova Ann. "Nigeria's Nationalization of British Petroleum." The International Journal of African Historical Studies 43, No. 1 (2010): 115-136.

Gore, Charles. "The Rise and Fall of the Washington Consensus as a Paradigm for Developing Countries,” World Development 28 (2000): 789-804.

Gould, John A, and Matthew S Winters. "An Obsolescing Bargain in Chad: Shifts in Leverage Between the Government and the World Bank,” Business and Politics 9, No. 2 (2007): 1-34.

Guriev, Sergei, Anton Kolotilin, and Konstantin Sonin, "Determinants of Nationalization in the Oil Sector: A Theory and Evidence from Panel Data," Journal of Law, Economics, and Organization 27, no. 2 (2011): 301-323.

Haber, Stephen, Noel Maurer, and Armando Razo. "When the Law Does Not Matter: The Rise and Decline of the Mexican Oil Industry.” The Journal of Economic History 63, no. 1 (2003): 1-32.

Harding, Thomas. "Dependency, Nationalism, and the State in Latin America." Latin 
American Perspectives 3, no. 4 (1976): 3-11.

Henisz, Witold. “The Institutional Environment for Infrastructure Investment.” Industrial and Corporate Change 11, No. 2 (2002): 355-389.

Henisz, Witold. "The Institutional Environment of Multinational Investment.” Journal of Law, Economics, and Organization 16, No. 12 (2000): 334-364.

Hoogvelt, Ankie. "Indigenization and Foreign Capital: Industrialization in Nigeria." Review of African Political Economy 6, No. 14 (1979): 56-68.

Jodice, David A. "Sources of Change in Third World Regimes for Foreign Direct Investment.” International Organization, 34, No. 2 (1980): 177-206.

Joffe, George, Paul Stevens, Tony George, Jonathan Lux, and Carol Searle. "Expropriation of Oil and Gas Investments: Historical, Legal, and Economic Perspectives in a New Age of Resource Nationalism.” Journal of World Energy, Law, and Business, 2, No. 1 (2009): 3-23.

Jones, Geoffrey, Decker, Stephanie. "Unilever as a multi-local multinational," Harvard Business School case (2007).

Kobrin, Stephen. "Diffusion as an Explanation of Oil Nationalization: Or the Domino Effect Rides Again.” Journal of Conflict Resolution, 29, No. 1 (1985): 3-32.

Kobrin, Stephen J. "Foreign Enterprise and Forced Divestment in LDCs," International Organization, 34, No. 1 (1980): 65-88.

Kobrin, Stephen J. "Expropriation as an Attempt to Control Foreign Firms in LDCs Trends from 1960 to 1979," International Studies Quarterly, 28, no. 3 (1984): $329-48$.

Kobrin, Stephen J. "Testing the Bargaining Hypothesis in the Manufacturing Sector in 
Developing Countries.” International Organization 41, no. 4 (1987): 609.

Lanciotti, Norma, and Andrea Lluch. "Foreign Direct Investment in Argentina: Timing of Entry and Business Activities of Foreign Cimpanies (1860-1950)." Entreprises et Histoire 54, no. 1 (2009): 37-66

Li, Quan. "Democracy, Autocracy, and Expropriation of Foreign Direct Investment." Comparative Political Studies, 42, No. 8 (2009): 1098-1127.

López-Alves, Fernando. "Visions of the National Natural Endowments, Futures, and the Evils of Men." In State and Nation Making in Latin America and Spain:

Republics of the Possible, edited by Miguel A. Centeno and Agustín Ferraro. Cambridge: Cambridge University Press, 2013.

Lubinski, Christina. "Liability of Foreignness in Historical Context: German Business in Preindependence India (1880-1940)." Enterprise \& Society 15, no. 4 (2014): 722 58.

Mahdavi, Paasha. "Why Do Leaders Nationalize the Oil Industry? The Politics of Resource Expropriation.” Energy Policy, 75 (2014): 228-243.

McCann, Bryan. “The Invention of Tradition in Brazilian Radio.” In The Brazil Reader: History, Culture, Politics, edited by Robert Levine and John J. Crocitti. Durham: Duke University Press, 1999.

Medina, Luis Fernando, Marcelo Bucheli, and Minyoung Kim. “Good Friends in High Places: Politico-Economic Determinants of the Expropriation and Taxation of Multinational Firms.” Journal of International Business Policy 2, No. 2 (2019): 119-141.. 
Mehlum, Halvor, Karl Moene, and Ragnar Torvik. "Institutions and the Resource Curse." The Economic Journal, 116, No. 508 (2006): 1-20.

Miller, Rory. "British Investment in Latin America, 1850-1950.” Itinerario 19, no. 3 (1995): 21-52.

Minor, Michael. "The Demise of Expropriation as an Instrument of LDC Policy, 19801992." Journal of International Business Studies 25, No. 1 (1994): 177-182.

Mittelman James H. "Underdevelopment and Nationalisation: Banking in Tanzania." The Journal of Modern African Studies 16, No. 4 (1978): 597-617.

Moran, Theodore. "Transnational Strategies of Protection and Defense by Multinational Corporations: Spreading the Risk and Raising the Cost for Nationalization in Natural Resources.” International Organization, 27, no. 2 (1973): 273-287.

Morgenstern, Scott J., Rubén Berríos, and Andrae Marak, “Explaining Hydrocarbon Nationalization in Latin America: Economics and Political Ideology," Review of International Political Economy, 18, No. 5 (2011): 673-697.

North, Douglass, William Summerhill, and Barry Weingast. “Order, Disorder, and Economic Change: Latin America Versus North America." In Governing for Prosperity, edited by Bruce Bueno de Mesquita and Hilton Root, 17-58. New Haven: Yale University Press, 2000.

Perchard, Andrew, Niall G. MacKenzie, Stephanie Decker, and Giovanni Favero. "Clio in the Business School: Historical Approaches in Strategy, International Business and Entrepreneurship.” Business History 59, no. 6 (February 17, 2017): 904-27. Portillo, Jorge. "Oil Nationalizations as Protracted Affairs: Evidence from Venezuela." OPEC Energy Review, 40, No. 1 (2016): 52-53. 
Redlich Fritz. Toward Comparative Historiography: Background and Problems. Kyklos 11, No. 3 (1958): 362-389.

Rood, Leslie. "Nationalisation and Indigenisation in Africa," The Journal of Modern African Studies 14, no. 03 (1976): 427-47.

Rood, Leslie L. "The Impact of Nationalisation.” The Journal of Modern African Studies 15, no. 03 (1977): 489-94.

Ross, Michael. “Does Oil Hinder Democracy? World Politics, 53, No. 3 (2001): 561-584.

Rüsen Jörn. Some Theoretical Approaches to Intercultural Comparative Historiography. History and Theory 35, no. 4 (1996): 5-22.

Rowlinson, Michael, John Hassard, and Stephanie Decker. "Research Strategies for Organizational History: A Dialogue between Historical Theory and Organization Theory." Academy of Management Review 39, no. 3 (2014): 205-74.

Sachs, Jeffrey and Andrew Warner. "The Curse of Natural Resources." European Economic Review 45 (2001): 827-838.

Skocpol, Theda, and Margaret Somers. "The Uses of Comparative History in Macrosocial Inquiry." Comparative Studies in Society and History 22, no. 2 (1980): 174-197.Smith, Andrew. "The Winds of Change and the End of the Comprador System in the Hongkong and Shanghai Banking Corporation.” Business History 58, no. 2 (2016): 179-206.

Snilstveit, Birte, Sandy Oliver, and Martina Vojtkova. "Narrative Approaches to Systematic Review and Synthesis of Evidence for International Development Policy and Practice." Journal of Development Effectiveness 4, no. 3 (September 2012): 409-29. 
Stevens, Charles, En Xie, and Mike Peng. "Towards a Legitimacy-Based View of Political Risk: The Case of Google and Yahoo in China." Strategic Management Journal, 37, No. 5 (2016): 954-963.

Uche, Chibuike Ugochukwu. "British government, British businesses, and the indigenization exercise in post-independence Nigeria." Business History Review 86, No. 4 (2013): 745-771.

Vivoda, Vlado. "Bargaining model for the international oil industry." Business \& Politics, 13, No. 4 (2011): 1469-3569.

Vivoda, Vlado. "Resource Nationalism, Bargaining and International Oil Companies: Challenges and Change in the New Millennium." New Political Economy, 14, No. 4 (2009): 517-534.

Waelde, Thomas. "International law of foreign investment: Towards regulation by multilateral treaties," Business Law International, 1 (1999): 50-79.

Williams, M. L. "The Extent and Significance of the Nationalization of Foreign-Owned Assets in Developing Countries, 1956-1972." Oxford Economic Papers, 27, No. 2 (1975): 260-273.

White, Nicholas J. British Business in Post-Colonial Malaysia, 1957 -70: NeoColonialism or Disengagement? RoutledgeCurzon Studies in the Modern History of Asia 21. London: RoutledgeCurzon, 2004.

White, Nicholas J. “The Business and the Politics of Decolonization: The British Experience in the Twentieth Century." Economic History Review 53, no. 3 (2000): 544-64. 
Wilson, Ernest. "Strategies of State Control of the Economy: Nationalization and Indigenization in Africa," Comparative Politics 22, no. 4 (1990): 401-19. Yacob, Shakila and Nicholas J. White. “The 'Unfinished Business' of Malaysia's Decolonisation: The Origins of the Guthrie 'Dawn Raid,'” Modern Asian Studies 44, no. 5 (2010): 919-960. 


\section{Figures and Tables}

\section{Figure 1: Case selection}

\begin{tabular}{|c|c|c|}
\hline & Nationalization & Indigenization \\
\hline Latin America & $\begin{array}{l}\text { Mexico } \\
\text { Chile } \\
\text { Venezuela }\end{array}$ & none \\
\hline $\begin{array}{l}\text { Sub-Saharan } \\
\text { Africa }\end{array}$ & $\begin{array}{l}\text { Tanzania } \\
\text { Zambia }\end{array}$ & $\begin{array}{l}\text { Nigeria } \\
\text { Ghana }\end{array}$ \\
\hline
\end{tabular}

\section{Table 1: Explanations of expropriations}

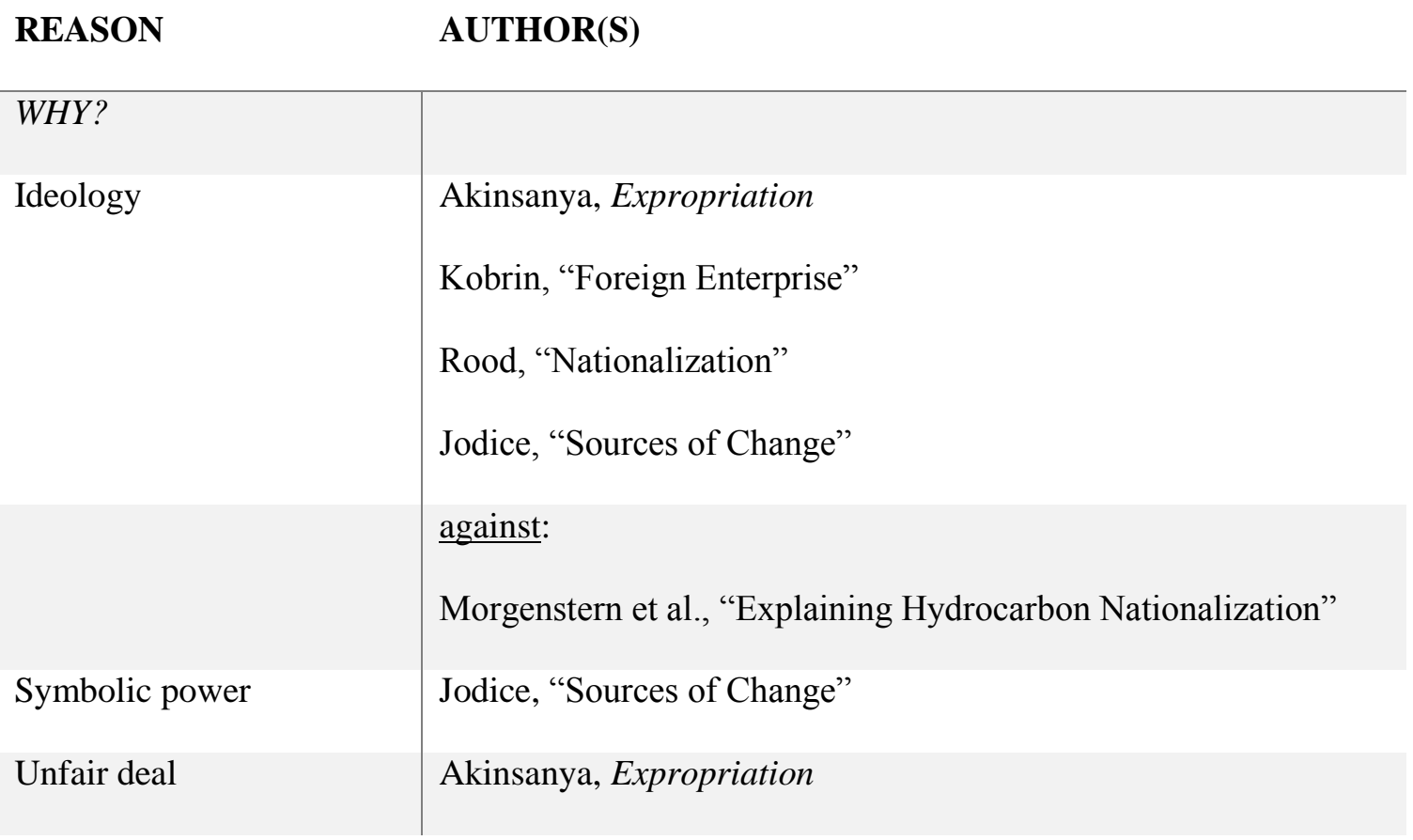




\begin{tabular}{|c|c|}
\hline & Mahdavi, "Why do leaders" \\
\hline Opportunity \& capability & $\begin{array}{l}\text { Guriev et al., "Determinants of Nationalization" } \\
\text { Mahdavi, "Why do leaders" }\end{array}$ \\
\hline $\begin{array}{l}\text { Effort to break } \\
\text { dependency }\end{array}$ & $\begin{array}{l}\text { Santos, "The Structure" } \\
\text { Santos, Imperialismo } \\
\text { Evans, Dependent Development } \\
\text { Harding, "Dependency, Nationalism, and the State" }\end{array}$ \\
\hline WHERE? & \\
\hline $\begin{array}{l}\text { Natural resource-seeking, } \\
\text { or sector specific } \\
\text { explanations }\end{array}$ & $\begin{array}{l}\text { Kobrin, "Foreign Enterprise" } \\
\text { Jodice, "Sources of Change" }\end{array}$ \\
\hline $\begin{array}{l}\text { Institutional quality / } \\
\text { authoritarian states }\end{array}$ & $\begin{array}{l}\text { Henisz, "The institutional environment of multinational } \\
\text { investment", "The institutional environment for infrastructure } \\
\text { investment" } \\
\text { Jensen, Nation States } \\
\text { Li, "Democracy" } \\
\text { Mahdavi, "Why do leaders" } \\
\text { Guriev et al., "Determinants of Nationalization" } \\
\text { Waelde, "International Law" }\end{array}$ \\
\hline & $\begin{array}{l}\text { against: } \\
\text { Duncan, "Price or Politics" }\end{array}$ \\
\hline Semi-peripheral countries & $\begin{array}{l}\text { Evans, Dependent Development } \\
\text { Santos, Imperialismo }\end{array}$ \\
\hline WHEN? & \\
\hline Radical political change & Kobrin, "Expropriation" \\
\hline
\end{tabular}




\begin{tabular}{l|l} 
Obsolescing bargain & $\begin{array}{l}\text { Ross, "Does oil" } \\
\text { Williams, "The extent and significance" } \\
\text { Vernon, Sovereignty at Bay } \\
\text { International prices for }\end{array}$ \\
Commodities & $\begin{array}{l}\text { Guriev et al., "Determinants of Nationalization" } \\
\text { Joffe et al. "Expropriation" } \\
\text { Vivoda, "Resource nationalism", "Bargaining model" } \\
\text { Mahdavi, "Why do leaders" } \\
\text { Bucheli, "Multinational Corporations" }\end{array}$
\end{tabular}

Figure 2: Expropriations of International Investments, 1960-1985

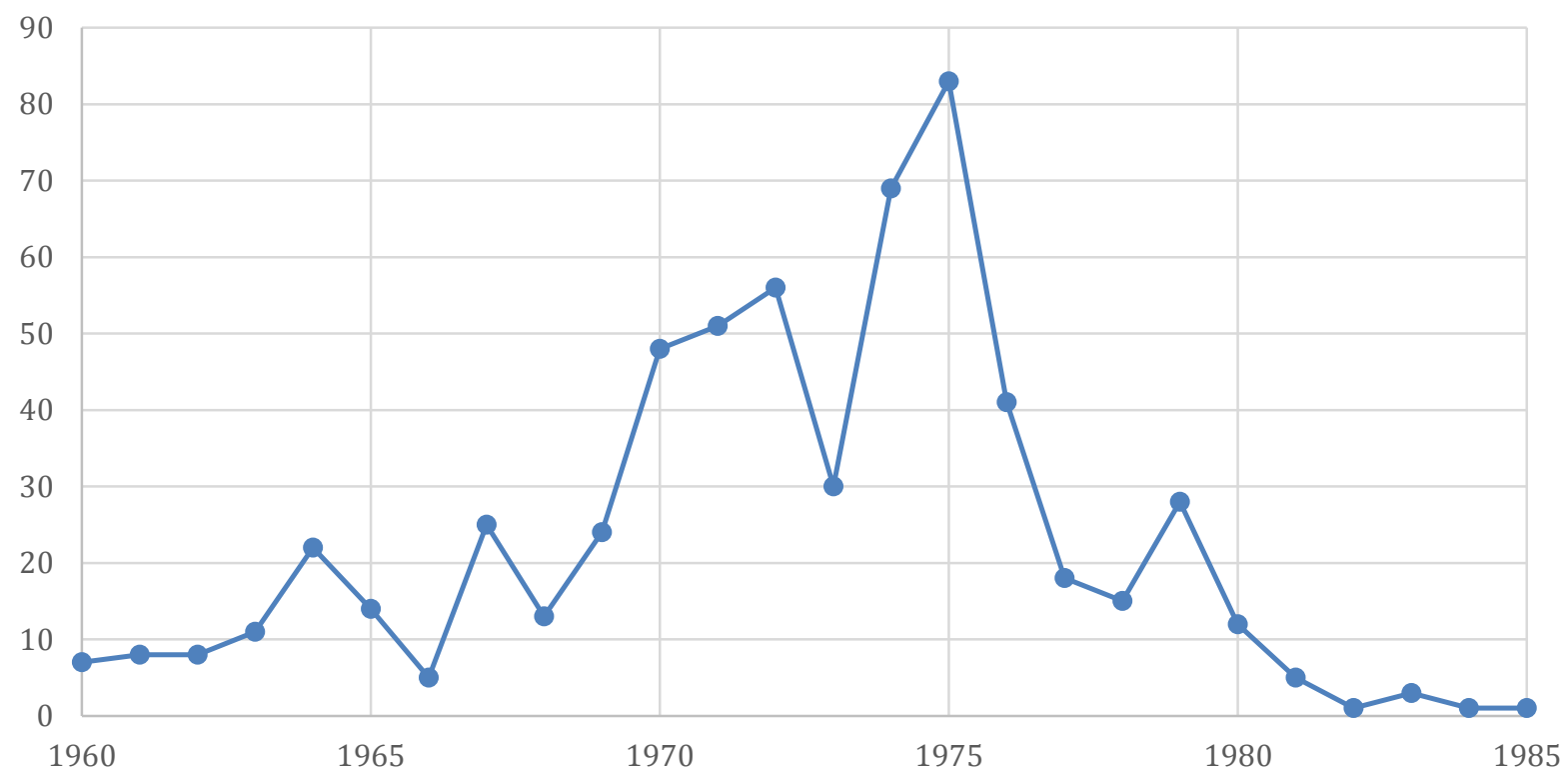

Source: Decker, Stephanie. “Corporate Legitimacy,” 78. 


\section{Table 2: Winning Alliances and Policies Towards Foreign Investors as Strategies for Political Survival}

\begin{tabular}{|c|c|c|c|}
\hline & $\begin{array}{c}\text { Alliance With Organized } \\
\text { Labor }\end{array}$ & $\begin{array}{c}\text { Alliance With Domestic Business } \\
\text { Community }\end{array}$ & $\begin{array}{c}\text { Alliance With State } \\
\text { Bureaucracy }\end{array}$ \\
\hline Policies & - Nationalization or & - Expropriation of small and & - Expropriation of large \\
\hline Towards & expropriation of large & medium foreign-owned & foreign-owned businesses \\
\hline Foreign & foreign corporations & businesses & - Creation of para-statal \\
\hline Property & $\begin{array}{l}\text { - Creation of state-owned } \\
\text { enterprises with powerful } \\
\text { unions }\end{array}$ & $\begin{array}{l}\text { - Indigenization } \\
\text { - Expropriation of foreign- } \\
\text { owned large companies for } \\
\text { the benefit of middle class } \\
\text { - Transfer of property to the } \\
\text { domestic private sector }\end{array}$ & $\begin{array}{l}\text { organizations to manage the } \\
\text { expropriated property } \\
\text { - Collectivization initiatives }\end{array}$ \\
\hline $\begin{array}{r}\text { Some } \\
\text { examples }\end{array}$ & $\begin{array}{l}\text { - Mexico from 1920-1938 } \\
\text { under Obregon, } \\
\text { Cardenas (petroleum) } \\
\text { - Chile (mining, telecoms) } \\
\text { - Venezuela (oil) }\end{array}$ & $\begin{array}{l}\text { - Mexico from 1915-1920 } \\
\text { under Carranza } \\
\text { - Ghana (SMEs, several } \\
\text { industries) } \\
\text { - } \quad \text { Nigeria (SMEs, several } \\
\text { industries) }\end{array}$ & $\begin{array}{l}\text { - Tanzania (several } \\
\text { industries) } \\
\text { - Zambia (mining) }\end{array}$ \\
\hline
\end{tabular}

${ }^{1}$ Wilkins, The Maturing, 33-44.

2 Jodice, "Sources of Change," 180-182.

${ }^{3}$ For an overview of the third wave of expropriations, see Wellhausen, The Shield.

${ }^{4}$ Kobrin, "Expropriation as an Attempt to Control"; Kobrin, "Testing the Bargaining Hypothesis." 
${ }^{5}$ Haber, Maurer, and Razo, "When the Law Does Not Matter"; Bucheli, "Canadian Multinational Corporations"; Bucheli and Salvaj, "Multinational Corporations' Obsolescing Political"; Decker, "Building up Goodwill"; Abdelrehim and Toms, "The Obsolescing Bargain Model and Oil”; Gould and Winters, "An Obsolescing Bargain in Chad"; Genova, "Nigeria's Nationalization of British Petroleum"; Uche, "British Government, British Businesses.”

${ }^{6}$ Redlich, “Toward Comparative Historiography”, 385-86.

${ }^{7}$ Noblit and Hare, Meta-Ethnography.

${ }^{8}$ Rood, "Nationalisation and Indigenisation in Africa"; Lipson, Standing Guard.

${ }^{9}$ Wellhausen, Shield, 24-25.

${ }^{10}$ Kobrin, "Foreign Enterprise;" Kobrin, "Expropriation.”

${ }^{11}$ Akinsanya, Expropriation, 78.

${ }^{12}$ Kobrin, "Foreign Enterprise," 69; Jodice, "Sources of Change," 178-179. An analysis of the expropriations carried out by left-wing Latin American governments in the 2000s also dismiss the role of ideology and emphasizes the opportunity created by high commodity prices (see, Morgenstern, Berríos, and Marak, "Explaining Hydrocarbon Nationalization")

${ }^{13}$ Akinsanya, Expropriation, 78-79; Mahdavi, "Why Do Leaders;" Jodice, "Sources of Change," 183.

${ }^{14}$ See Guriev, Kolotilin, and Sonin, "Determinants;" Kobrin, "Foreign Enterprise;" Mahdavi, "Why Do Leaders Nationalize;" Kobrin, “Expropriation,” 341.

${ }^{15}$ For the most complete study on how the American government protected U.S corporations from expropriation threats see Maurer, The Empire Trap. 
${ }^{16}$ Kobrin, "Foreign Enterprise," 76; Jodice, “Sources of Change," 182.

${ }^{17}$ Kobrin maintains that manufacturing represented around 46 percent of all expropriations during the 1960s-1970s expropriation wave, while Jodice calculates 27 percent. See, Kobrin, "Foreign Enterprise," 78-81; Jodice, "Sources of Change," 182.

${ }^{18}$ Kobrin, "Foreign Enterprise," 86.

${ }^{19}$ Henisz, "Institutional Environment;” Henisz, "Institutional Environment;” Jensen, Nation States.

${ }^{20} \mathrm{Li}$, “Democracy,” 1098-1099, 104-105.

${ }^{21}$ Mahdavi, "Why Do Leaders," 231-232; Guriev, Kolotilin, and Sonin, "Determinants." Waelde makes an interesting interpretation by pointing out that the very understanding of what a contract is differs between Western democracies and underdeveloped countries.

See, Waelde, “International Energy,” 211.

22 Dos Santos, “The Structure of Dependence,” 233.

23 Evans, Dependent Development, 184-194.

24 Dos Santos, Imperialismo y dependencia, 27-28, 336-339, 465.

25 Harding, “Dependency," 3-11.

${ }^{26}$ Kobrin, "Foreign Enterprise," 70, 86.

27 Medina, Bucheli, Kim, “Good Friends.”

${ }^{28}$ Guriev, Kolotilin, and Sonin, “Determinants;” Joffe, Stevens, George, Lux, and Searle, “Expropriation;" Vivoda, "Resource Nationalism.

29 Jodice, “Sources of Change," 177.

${ }^{30} \mathrm{Li}$, “Democracy” 1102.

${ }^{31}$ Li, “Democracy," 1122. 
${ }^{32}$ Kobrin, "Testing the Bargaining Hypothesis;" Kobrin, "Expropriation;" Minor, "The Demise of Expropriation."

${ }^{33}$ Rood, "Nationalisation and Indigenisation in Africa"; Rood, "The Impact of Nationalisation"; Kobrin, "Expropriation as an Attempt to Control."

${ }^{34}$ Decker, "Building up Goodwill"; Haber, Maurer, and Razo, "When the Law Does Not Matter"; Bucheli and Salvaj, "Multinational Corporations' Obsolescing Political."

${ }^{35}$ Moran, Multinational Corporations; Biersteker, Multinationals.

${ }^{36}$ Rowlinson, Hassard, and Decker, "Research Strategies for Organizational History"

37 The major exceptions to this are the ideologically motivated expropriations in the Eastern bloc.

${ }^{38}$ For an overview of the development of economic nationalism in Eastern Europe, see Schultz and Kubi, History and Culture. An overview of expropriations in Latin America can be found in Sigmund, Multinationals.

${ }^{39}$ Minor, "The Demise of Expropriation," 179.

${ }^{40}$ Haber, Razo, and Maurer, The Politics of Property Rights, 47.

${ }^{41}$ Garner, British Lions, 138-165.

${ }^{42}$ Brown, Oil and Revolution, 212-219.

${ }^{43}$ Haber, Razo, Maurer, The Politics of Property Rights.

${ }^{44}$ Brown, "Why Foreign Oil Companies Shifted."

45 Portillo, "Oil Nationalizations," 52-53.

46 Tugwell, The Politics of Oil, 50-85.

${ }^{47}$ DiJohn, From Windfall to Curse? 15-32.

${ }^{48}$ McBeth, La política petrolera, 15-54. 
${ }^{49}$ Bermúdez Romero, PDVSA; Ellner, “Trade Union Autonomy,” 77-79.

${ }^{50}$ Moran, Multinational Corporations, 126-127

${ }^{51}$ In fact, in the 1940s an alliance supporting the creation of a national monopoly between the Chilean business elites and the government was created. This alliance, however, broke down in the 1950s during the pro-market Jorge Alessandri government. See Moran, Multinational Corporations, 119.

52 Moran, Multinational Corporations, 119-152; Bucheli and Salvaj, "Reputation."

53 This has also been discussed for French Canada, see Breton, "The Economics of Nationalism."

${ }^{54}$ North, Summerhill, and Weingast, “Order,”17-58; Bucheli and Kim, “Attacked from Both Sides;" Haber, Razo, Maurer, The Politics of Property Rights.

55 Breton, "The Economics of Nationalism."

${ }^{56}$ Cooper, Africa Since 1940, 38-65; Aminzade, “The Dialectic of Nation Building."

${ }^{57}$ Decker, "Building up Goodwill;" Esseks, "Economic Policies,” 37-61.

58 Fieldhouse, Merchant Capital, 626-632.

${ }^{59}$ Decker, "The emergence of Africanization."

${ }^{60}$ Cooper, Decolonization, 468-469; Freund, The African Worker, 18-20, 97-109.

${ }^{61}$ There is a large body of scholarly literature on the resource curse. Some good overviews include Mehlum, Moene, and Torvik, "Institutions;" Sachs and Warner, "The Curse.”

${ }^{62}$ Genova, "Nigeria's Nationalization of British Petroleum"; Uche, "British Government, British Businesses, and the Indigenization Exercise in Post-Independence Nigeria.”

${ }^{63}$ Jones and Decker, Unilever; Hoogvelt, "Indigenization.” 
${ }^{64}$ This has been argued for the time period since 2000 by Linsi, "The Two Political Economies."

${ }^{65}$ Biersteker, Multinationals, 7, 52-96; Fielhouse, Merchant Capital, 646-662.

${ }^{66}$ Bayart, The State in Africa, 100-103.

${ }^{67}$ Collins, "The Political Economy of Indigenization;” Tom Forrest, The Advance of African Capital, 243-244; Biersteker, Multinationals.

${ }^{68}$ Decker, "Dekolonisation Der Wirtschaft?;“"Rood, "Nationalization.“

${ }^{69}$ Nugent, Africa, 141-153; Scott, Seeing like a State, 141-153.

${ }^{70}$ Nugent, Africa, 142.

${ }^{71}$ Breton, "The Economics of Nationalism," 376-386.

72 Aminzade, "The Dialectic of Nation Building."

${ }^{73}$ Mittelman, "Underdevelopment and Nationalisation."

${ }^{74}$ Aminzade, "The Dialectic of Nation Building."

${ }^{75}$ Mittelman, "Underdevelopment and Nationalisation."

${ }^{76}$ Aminzade, "The Dialectic of Nation Building."

${ }^{77}$ Nugent, Africa, 152-153.

${ }^{78}$ Fieldhouse, Black Africa, 173-186.

${ }^{79}$ Sklar, Corporate Power, 96-216; Butler, Copper Empire, 293-299; Butler, "Mining, Nationalism, 1-17.

${ }^{80}$ Burdette, "Nationalization in Zambia."

${ }^{81}$ Wilson, "Strategies of State Control."

${ }^{82}$ Sardanis, A Venture in Africa.

${ }^{83}$ Sklar, Corporate Power, 192-204; Burdette, "Nationalization." 
${ }^{84}$ Decker, "Postcolonial Transitions"

${ }^{85}$ Burdette, "Nationalization."

${ }^{86}$ Decker, "Building up Goodwill”; White, "The Business and the Politics of

Decolonization"; Stockwell, The Business of Decolonization; Butler, Copper Empire; Maurer, The Empire Trap; Bucheli, "Multinational Corporations, Totalitarian Regimes"; Yacob and White, “The 'Unfinished Business' of Malaysia's Decolonisation”; Miller, "British Investement"; Lanciotti and Lluch, "Foreign Direct Investment in Argentina"; Uche, "British Government, British Businesses"; Genova, "Nigeria's Nationalization of British Petroleum”; Afrifa Taylor, “An Economic History”; Smith, “The Winds of Change"; Lubinski, "Liability of Foreignness."

${ }^{87}$ Several business historians have argued that a greater focus on theoretical contributions is needed: Perchard, MacKenzie, Decker, and Favero. "Clio in the Business School"; Wadhwani and Bucheli. "The Future of the Past." ${ }^{88}$ Skocpol and Somers, "The Uses of Comparative History”; Redlich, “Toward Comparative Historiography".

${ }^{89}$ Rüsen, "Some Theoretical Approaches”; Lorenz, “Comparative Historiography”.

${ }^{90}$ Hobsbawm, Nations and Nationalism, 99; Anderson, Imagined Communities.

${ }^{91}$ Hobsbawm, Nations and Nationalism, 160.

${ }^{92}$ E.g. Kobrin, “Expropriation.”; Nairn, The Break-Up of Britain, 337-341.

${ }^{93}$ Beckman, Capital Fictions, xiii-xiv, 4-6.

${ }^{94}$ López-Alves, "Visions of the National Natural Endowments, 294-319. 
${ }^{95}$ See, Ceresole, Perú, 112 (Peru), Rodríguez González, En mala compañáa, 50

(Venezuela); Patiño, El discurso, 153 (Ecuador); Bryan McCann, "The Invention of Tradition," 479 (Brazil).

${ }^{96}$ Breton, "The Economics of Nationalism."

${ }^{97}$ This does not mean that other type of conflicts were not present. A religious war between pious Catholic peasants against a secular government took place in Mexico between 1926 and 1929, while other regional ethnic wars unfolded in different countries. However, the basic ideas of the nation-state were not seriously challenged in either of these conflicts.

${ }^{98}$ Aminzade, "The Dialectic."

${ }^{99}$ Englebert, "Pre-Colonial Institutions."

${ }^{100}$ Darwin, "Decolonization;” Holland, European Decolonization.

${ }^{101}$ Nugent, Africa since Independence, 204-325; Cooper, Africa since 2004, 133-155.

${ }^{102}$ Bucheli and Kim, "The State;" Stevens, Xie, and Peng, "Towards a Legitimacy-Based View."

${ }^{103}$ Burawoy, The Color of Class; Butler, Copper Empire; Sklar, Corporate Power. ${ }^{104}$ Stephanie Decker, "Building Up Goodwill."

${ }^{105}$ Schneider, Business Politics, 11-12.

${ }^{106}$ Although used in a large number of academic papers, the best source for this theory is Bueno de Mesquita, Smith, Siverson, and Morrow, The Logic of Political Survival. ${ }^{107}$ Bueno de Mesquita, et al., The Logic of Political Survival, define the "selectorate" as those electing the ruler (including but not necessarily through elections) and the "winning 
coalition" as the sub-section of the selectorate that has the power to define whether the ruler stays in power, whether by mobilizing the selectorate or acting on its own (41-43). ${ }^{108}$ Eggerston, Imperfect Institutions, 64.

${ }^{109}$ Bates, Markets and States, 6-7, 120-121.

${ }^{110}$ Collins, "The Political Economy of Indigenization"; Biersteker, Multinationals.

${ }^{111}$ Wilson, "Strategies of State Control of the Economy." 